\title{
FEATURES OF INFLAMMATORY REACTION IN RATS TO IMPLANTATION OF MODERN MESH ENDOPROSTHESES FOR HERNIA REPAIR
}

\author{
Kchibekov E.A. ${ }^{1}$, Kokhanov A.V. ${ }^{1}$, Kaliev D.R. ${ }^{1}$, Kudaev S.V. ${ }^{1}$, Bondarev V.A. ${ }^{1}$, \\ Serdyukov M.A. ${ }^{1}$
}

${ }^{1}$ Astrakhan State Medical University, Astrakhan, e-mail: agma@astranet.ru

\begin{abstract}
Aims.
To compare in a rat experiment the nature of local proliferative inflammatory reaction induced by a foreign body, at different times after implantation of polypropylene and metal mesh hernia prostheses of different manufacturers.

Materials and methods.

In experiments with rats of the Wistar line, the nature of local proliferative inflammatory reaction induced by a foreign body was studied at different times after implantation of the four polypropylene, one Teflon, and one metal mesh hernia prosthesis of different manufacturers. Along with the histological examination of the encapsulated mesh implant, two morphometric parameters of aseptic proliferative inflammation were assessed: mass of the connective-tissue capsule around the foreign body and its thickness.

Results.

It is found that the minimum fibrous capsule forms after implantation of the domestic polypropylene mesh endoprosthesis Esfil. A moderate proliferative inflammatory reaction is caused by the polypropylene implant Optomesh. A more severe reaction in rats is induced by B.Braun and ERGON lightweight polypropylene mesh endoprosthesis. The maximum fibrous capsule forms after implantation of mesh implants of two-layer porous polytetrafluoroethylene Dualmesh (Gore-Tex, USA) and domestic metal endoprosthesis "Titanium silk" in rats.

Conclusions.
\end{abstract}

The obtained results should be considered when choosing a mesh prosthesis for hernia repair. In particular, the "Titanium silk" endoprosthesis made of high-purity titanium filaments can be effectively used as a prosthesis for hernia repair.

Keywords: mesh endoprostheses for the treatment of ventral hernias, subcutaneous implantation in rats, mass and thickness of the fibrous capsule, features of proliferative inflammation.

\section{INTRODUCTION.}

Optimizing surgical repair of hernias in the anterior abdominal wall is a pressing task of today's surgery $[1 ; 2]$. Since synthetic mesh patches appeared as a tool for strengthening the newly formed anterior abdominal wall, ventral hernia recurrence, which had earlier ranged from $10 \%$ to $45.5 \%$ according to various sources, has dropped dramatically. Today, synthetic alloprosthetic surgery of the abdominal wall is the golden standard of ventral hernia repair [3-5]. Synthetic explants are used in about a million hernioplasties per annum [3;6]. This reduced the recurrence rate to $10 \%$ and enabled the repair of extensively affected abdominal walls, which used to be considered untreatable $[1 ; 2 ; 6 ; 7]$.

Today's Russian and international chemical industries produce strong synthetic patches that are relatively inert biologically $[3 ; 5 ; 7]$. The most optimal prosthetic materials of today are polypropylene (PP) and polytetrafluorethylene (PTFE, also known as Teflon) $[4 ; 8]$; other materials such as nylon, carbon fiber, and polyester have limited use, while silver wire, stainless steel, polyvinyl, Mylar, polyethylene, Fortisan, fiberglass, and dissolving prostheses based on polyglycolic acid and polyglactin have been proven unsuitable [8; 9].

However, the basic types of PTFE and PP-based hernioplasty patches also have their 
drawbacks; thus, Teflon attaches poorly to tissue, which causes patch displacement and recurrence. PP induces the emergence of a coarse connective-tissue capsule that shrinks the hernia patch [9; 10]. Besides, the use of synthetic materials for hernioplasty has recently been found to cause previously non-encountered complications. The synthetic implant might travel to the abdominal cavity; the mesh-to-intestine adhesion may cause adhesive bowel obstruction; a fistula may emerge as a result of the patch-related ulceration of the intestinal wall; or seromas might appear at the implantation site, to name a few [9-11]. Thus, it is still urgent to find such plastic material that would make a perfect hernia patch, i.e. both strong and as histocompatible as possible $[10 ; 11]$.

The newest Russian product, Titanium Silk (Ti Silk), shows great promise; it is a high-purity BT 1.00 Ti filament woven into patches for soft tissue. Implants of pure titanium or Nitinol-based alloys (NA) are highly elastic due to special weaving. Some of the clinics in Siberia and TransUrals have extensively researched the specifics of Ti and NA, and still prefer NA over any synthetic material [12].

To date, surgeons find satisfactory the mechanical properties of state-of-the-art metal, polypropylene, and composite mesh patches $[1-3 ; 12]$; however, reducing the inflammatory response to polypropylene implants to avoid complications typical of hernioplasty remains an urgent problem $[6 ; 7 ; 9 ; 11]$.

Research Goal. Experiment on rats to compare local proliferative inflammatory response induced by a foreign body at different times after implanting polypropylene and metal mesh hernia patches from various manufacturers.

MATERIALS AND METHODS.

Experiments were run on 48 male Wistar rats bred at the Leprosy Research Institute of the Ministry of Health, Astrakhan; the animals weighed 150 to $170 \mathrm{~g}$ and were randomly split into 6 experimental groups, 8 specimens each, one group per type of mesh patch. The rats were kept in a vivarium at $20^{\circ}$ to $22^{\circ}$ with sunlight only, a maximum of 4 animals per cage; the conditions were the same for each animal, and the diet was a standard one.

The animal experiments followed the European Convention for the Protection of Vertebrate Animals Used for Experimental and other Scientific Purposes (Strasbourg, March 18, 1986), ETS N 123, as well as the Order of the Ministry of Health No. 199N On the Approval of Good Laboratory Practice Rules, April 1, 2016.

The experiments used lightweight last-gen mesh patches made of monofilament polypropylene, a total of 4 brands: Esfil Light (Lintex, St. Petersburg, Russia), Ergon (ERGON EST, Italy), Optilene Mesh LP (B. Braun, Germany), and Optomesh®ThinLight (Matopat, Poland), as well as 1 porous two-layer polytetrafluoroethylene patch: Dual-mesh (Gore-Tex, USA). Group 6 had metal mesh patches made of titanium filament, Titanium Silk (Ti Silk) from NPF TEMP LLC, Yekaterinburg, Russia. Torsion scales were used to weigh each implant per square $\mathrm{cm}$; sterile square implants sized $5 \times 5 \mathrm{~mm}$ or $1 / 4 \mathrm{~cm}^{2}$ were used for surgery. The implanted synthetic square fragments as weighed by torsion scales ranged from 4 to $6 \mathrm{mg}$, while their Ti Silk counterparts of the same size weighted $18 \pm 0.2 \mathrm{mg}$, see Table. 
The surgery was performed as follows: rats had their interscapular region pre-shaved and sanitized; a 5-mm-long cut was made with a scalpel in the skin of rats under ethereal anesthesia, and sterile fragments of mesh patches were introduced in the wound in 4 directions to a depth of 1.5 to $2 \mathrm{~cm}$ by means of tweezers. The wound was not stitched, as the suture material could affect the inflammation and regeneration processes.

After surgery, the animals were kept alone; they were withdrawn from the experiment on Days 1, 3, 7, and 21 by anesthetic overdose pursuant to the Convention. All the 4 implants of a single rat and 3 implants of another rat from the same group were then be separated together with the capsules formed around them and dried at $60{ }^{\circ} \mathrm{C}$ over 24 hours; then the mean weight of dry capsules was calculated exclusive of the weight of the original implant; the fourth implant of the second rat, its capsule and skin were tested histologically. Tissue pieces and the patch were fixed and paraffin-poured. Cuts were stained with hematoxylin-eosin per Van Gieson and Weigert, impregnated per Foot. An ocular micrometer was used to measure the thickness of the connectivetissue capsule in microns $(\mu \mathrm{m})$ at 50 points in hematoxylin-eosin-stained preparations [9].

The results were subject to statistical processing using Statistica 12.0, StatSoft Inc., and Microsoft Excel 2003. Statistical processing used descriptive statistics and correlation analysis. For features that had a normal distribution, the research team calculated the arithmetic mean and the error, $\mathrm{M} \pm \mathrm{m}$, to be compared by Student's t-test. Mann-Whitney’s U-test was run for features with other than the normal distribution. The significance threshold was $\mathrm{p}<0.05$.

RESULTS. The weight of implanted fragments sized $1 / 4 \mathrm{~cm}^{2}$ did not differ significantly in 4 mesh types, ranged from 4 to $5 \mathrm{mg}$, see Table; B. Braun had an original mean weight of $5.7 \pm 0.26 \mathrm{mg}$, while Ti Silk weighed $19.0 \pm 0.58 \mathrm{mg}$, both significantly heavier than their counterparts. Note that the specific weight of any mesh patch was 2 to 6 times that specified by the manufacturers. According to the authors' calculations, Esfil weighed $16.5 \mathrm{mg} / \mathrm{cm}^{2}\left(165 \mathrm{~g} / \mathrm{cm}^{2}\right)$, Ergon weighed $16.3 \mathrm{mg} / \mathrm{cm}^{2}\left(163 \mathrm{~g} / \mathrm{m}^{2}\right)$, Optilene (B. Braun) had a density of $23 \mathrm{mg} / \mathrm{cm}^{2}(230$ $\left.\mathrm{g} / \mathrm{m}^{2}\right)$, and Optomesh was $19 \mathrm{mg} / \mathrm{cm}^{2}\left(190 \mathrm{~g} / \mathrm{m}^{2}\right)$, while their manufacturers specified 28 to $36 \mathrm{~g} / \mathrm{m}^{2}$. Dual-mesh weighed $18 \mathrm{mg} / \mathrm{cm}^{2}\left(180 \mathrm{~g} / \mathrm{m}^{2}\right)$ rather than the manufacturer-specified $120 \mathrm{~g} / \mathrm{m}^{2}$, while Ti Silk was $76 \mathrm{mg} / \mathrm{cm}^{2}\left(760 \mathrm{~g} / \mathrm{m}^{2}\right)$ rather than $120 \mathrm{~g} / \mathrm{m}^{2}$.

One day after surgery, rats already showed proliferative inflammatory response with a connective-tissue capsule being formed around the foreign body.

Microscopy of the cut samples of encapsulated implants taken on different postoperative days showed the same outcome for any type of mesh patch: the implant was surrounded by a connective-tissue capsule between striated muscles under subcutaneous fat. The connective tissue contained collagen, elastin, and argyrophilic fibers, cellular elements (mainly fibroblasts), as well as enormous foreign-body cells and macrophages on the inner surface closer to the implant. The newly formed tissue sampled on Days 7 and 21 was rich in arterioles, venules, and capillaries. The capsule was morphologically non-homogeneous through thickness, as the capsule had compact, collagen- 
rich connective tissue adjacent to the implant; looser connective tissue with collagen and elastic fibers, as well as numerous fibroblasts peripherally. Foot's impregnation revealed multiple argyrophilic fibers at the patch-capsule interface and within the meshes, as well as at the capsulemuscle interface.

However, no significant difference was found in the structure or the cellular composition of the connective-tissue capsule regardless of the implant type. At the same time, the difference was indeed significant in terms of proliferation intensity and patterns in the morphometric parameters of the fibrous capsule, see Figure, Table.

Minimum-weight connective-tissue capsules (6-7 mg) emerged on Day 1 around Esfil and Optomesh patches, see Table. Significantly $(\mathrm{p}<0.05)$ heavier $(8.7 \pm 0.59$ and $9.3 \pm 0.55 \mathrm{mg})$ capsules emerged around Ergon and B.Braun polypropylene implants; however, fibrous capsules around Dual-mesh and Ti Silk differed the most $(11.2 \pm 0.66$ and $13.4 \pm 1.37 \mathrm{mg})$ from their Esfil counterparts $(\mathrm{p}<0.05)$.

Day 1 fibrous capsules were least thick (110 to $115 \mu \mathrm{m}$ ) around Esfil, Ergon, and Optomesh meshes, see Table. The B. Braun capsule had a mean thickness of $144 \pm 11.9 \mu \mathrm{m}$ (the difference between it and Esfil was insignificant); only Dual-mesh and Ti Silk had statistically thicker fibrous capsules than Esfil at $156 \pm 13.6$ and $158 \pm 13.0 \mu \mathrm{m}(\mathrm{p}<0.05)$.

The thickness of capsular walls around the mesh patches as measured by microscopy at 50 points varied significantly from direction to direction, resulting in a great measurement error and thus making this indicator less informative for finding the difference between synthetic implant types than the dry capsule weight, see Table.

Of all implanted mesh patches, a fibrous capsule built up at the lowest rate throughout the entire observation term around the Russian Esfil implant: the dry periimplant capsule weight rose to 10.2 $\pm 0.64 \mathrm{mg}$ on Day 3 or $1.6 \times$ the Day 1 weight; $19.7 \pm 0.81 \mathrm{mg}$ on Day 7 , i.e. nearly $2 \times$ the Day 3 weight and $>3.1 \times$ the Day 1 weight. By Day 21, it rose to $23.5 \pm 1.53 \mathrm{mg}$; however, the rate declined, as the Day 21 weight was only 1.2 times that on Day 7, see Table, Figure.

Fibrous capsule walls were also the thinnest around Esfil meshes of any implanted patches throughout the study: $217 \pm 17.5 \mu \mathrm{m}$ on Day $3,413 \pm 39.2 \mu \mathrm{m}$ on Day 7 , and $591 \pm 56.4 \mu \mathrm{m}$ on Day 21 . For this reason, the fibrous capsule buildup rate for other mesh patches was compared against that of Esfil, as the Esfil implants triggered the weakest proliferative inflammatory response.

How implanting mesh patches affected the morphometry of aseptic proliferative inflammatory response in rats

\begin{tabular}{|l|c|c|c|c|c|c|c|}
\hline Indicator & Day & \multicolumn{5}{|c|}{ Implant type } \\
\hline & & Esfil & ERGON & B.Braun & Optomesh & Dual-mesh & Ti Silk \\
\hline $\begin{array}{l}\text { Welght } \\
\text { of the implant, } \\
\text { mg }\end{array}$ & & $4.1 \pm 0.15$ & $4.1 \pm 0.17$ & $5.7 \pm 0.26^{*}$ & $4.8 \pm 0.20$ & $4.6 \pm 0.18$ & $19.0 \pm 0.58$ \\
\hline Dry capsule & 1 & $6.3 \pm 0.38$ & $8.7 \pm 0.59^{*}$ & $9.3 \pm 0.55^{*}$ & $6.9 \pm 0.69$ & $11.2 \pm 0.66^{*}$ & $13.4 \pm 1.37^{*}$ \\
\hline
\end{tabular}




\begin{tabular}{|l|c|c|c|c|c|c|c|}
\cline { 2 - 7 } $\begin{array}{l}\text { weight, mg, } \\
\mathrm{n}=7\end{array}$ & 3 & $10.2 \pm 0.64 *$ & $14.1 \pm 0.81 *$ & $17.0 \pm 1.00^{*}$ & $\begin{array}{c}12.2 \pm 0.72 \\
*\end{array}$ & $15.9 \pm 1.22^{*}$ & $18.5 \pm 1.71^{*}$ \\
\cline { 2 - 8 } & 7 & $19.7 \pm 0.81 *$ & $32.8 \pm 2.29 *$ & $31.4 \pm 2.77 *$ & $\begin{array}{c}21.5 \pm 2.53 \\
*\end{array}$ & $26.4 \pm 2.15$ & $27.6 \pm 1.94 *$ \\
\cline { 2 - 8 } & 21 & $23.5 \pm 1.53$ & $38.4 \pm 2.12^{*}$ & $36.1 \pm 9.3 *$ & $27.9 \pm 2.69$ & $39.9 \pm 1.60$ & $30.3 \pm 1.65^{*}$ \\
\hline $\begin{array}{l}\text { Capsule wall } \\
\text { thickness, } \mu \mathrm{m}, \\
\mathrm{n}=50\end{array}$ & 1 & $114 \pm 10.2$ & $111 \pm 11.3$ & $144 \pm 11.9$ & $110 \pm 9.6$ & $156 \pm 13.6^{*}$ & $158 \pm 13.0^{*}$ \\
\cline { 2 - 8 } & 3 & $217 \pm 17.5$ & $234 \pm 17.6$ & $283 \pm 24.5 *$ & $269 \pm 22.6 *$ & $295 \pm 26.0^{*}$ & $309 \pm 27.2^{*}$ \\
\cline { 2 - 8 } & 7 & $413 \pm 39.2$ & $455 \pm 46.6$ & $494 \pm 44.2$ & $403 \pm 35.8$ & $537 \pm 45.4^{*}$ & $545 \pm 49.1^{*}$ \\
\cline { 2 - 8 } & 21 & $591 \pm 56.4$ & $670 \pm 71.0$ & $735 \pm 68.4$ & $568 \pm 53.7$ & $777 \pm 69.7 *$ & $692 \pm 60.5$ \\
\hline
\end{tabular}

Note: * stands for a significant difference compared to Esfil $(\mathrm{p}<0.05)$.

Optomesh did not differ significantly throughout the study from Esfil in terms of fibrous capsule weight, thickness, and buildup rate, see Table and Figure.

A rather large fibrous capsule formed around the Italian-made Ergon PP mesh patch: $8.7 \pm 0.59 \mathrm{mg}$ and $111 \pm 11.3 \mu \mathrm{m}$ on Day $1 ; 14.1 \pm 0.81 \mathrm{mg}$ and $234 \pm 17.6 \mu \mathrm{m}$ on Day $3 ; 32.8 \pm 2.29 \mathrm{mg}$ and $455 \pm 46.6 \mu \mathrm{m}$ on Day 7; and $32.8 \pm 2.29 \mathrm{mg}$ and $670 \pm 71.0 \mu \mathrm{m}$ on Day 21 . At any time, the dry capsule weight did differ significantly from that around Esfil implants $(\mathrm{p}<0.05)$, but thickness did not, see Table. 
Similar patterns and intensive connective tissue growth in the mesh were observed for B. Braun patches as reflected by the fibrous capsule weight and thickness patterns: $9.3 \pm 0.55 \mathrm{mg}$ $(\mathrm{p}<0.05)$ and $144 \pm 11.9 \mu \mathrm{m}$ on Day $1 ; 17.0 \pm 1.00 \mathrm{mg}(\mathrm{p}<0.05)$ and $283 \pm 24.5 \mu \mathrm{m}(\mathrm{p}<0.05)$ on Day 3; $31.4 \pm 2.77 \mathrm{mg}$ and $494 \pm 44.2 \mu \mathrm{m}$ on Day $7 ; 36.1 \pm 9.3 \mu \mathrm{m}(\mathrm{p}<0.05)$ and $735 \pm 68.4 \mu \mathrm{m}$ on Day 21, respectively, see Table and Figure.

It is notable is that the Ergon and B. Braun fibrous capsule growth rate peaked between Days 3 and 7, see Figure.
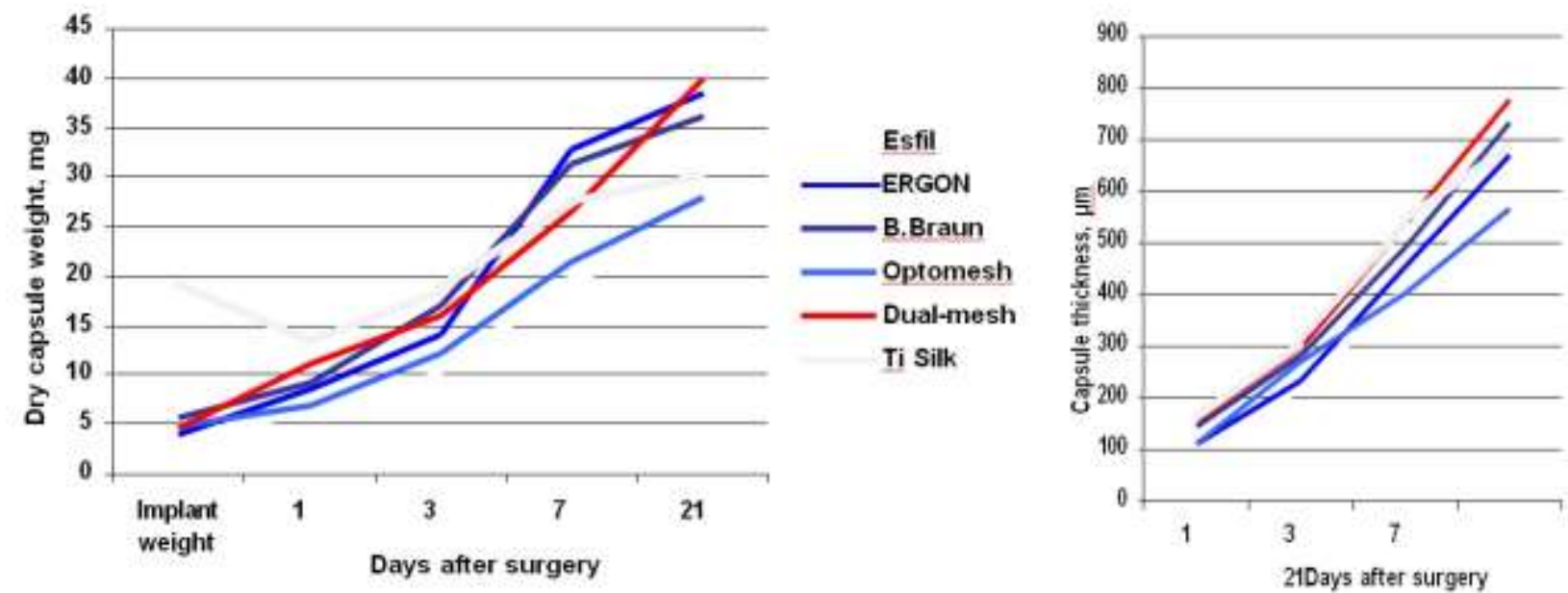

Fibrous capsule weight and thickness on different post-surgery days

Dual-mesh, a two-layer Teflon patch, had the greatest fibrous tissue growth and strongest proliferative inflammatory response after Day 7, see Table and Figure: the fibrous capsules had a mean weight and thickness of $11.2 \pm 0.66 \mathrm{mg}$ and $156 \pm 13.6 \mu \mathrm{m}(\mathrm{p}<0.05)$, respectively, on Day 1; $15.9 \pm 1.22 \mathrm{mg}$ and $295 \pm 26.0 \mu \mathrm{m}$ on Day $3 ; 26.4 \pm 2.15 \mathrm{mg}$ and $537 \pm 45.4 \mu \mathrm{m}$ on Day 7 ; and $39.9 \pm 1.60 \mathrm{mg}$ and $777 \pm 69.7 \mu \mathrm{m}$ on Day 21 .

Implanting a titanium mesh was associated with a strong proliferative inflammatory response to Ti Silk from Day 1, which induced the emergence of a significantly $(\mathrm{p}<0.05)$ larger fibrous capsule on Days $1(13.4 \pm 1.37 \mathrm{mg}$ and $158 \pm 13.0 \mu \mathrm{m})$ and $3(18.5 \pm 1.71 \mathrm{mg}$ and $309 \pm 27.2 \mu \mathrm{m}$ ). However, by Days 7 and 21, the fibrous capsule weight and thickness increase rates dropped considerably compared to Dual-mesh or even Ergon or B. Braun: $27.6 \pm 1.94 \mathrm{mg}(\mathrm{p}<0.05)$ and $545 \pm 49.1 \mu \mathrm{m}(\mathrm{p}<0.05)$ on Day 7; 30.3 $\pm 1.65 \mathrm{mg}(\mathrm{p}<0.05)$ and $692 \pm 60.5 \mu \mathrm{m}$ on Day 21, although the capsules did continue to grow significantly thicker up to the last observation day, see Table and Figure.

Thus, the Teflon and titanium meshes, similarly to some of their polypropylene counterparts, effectively had one non-mechanical function: they induced continuous inflammation and collagen generation.

CONCLUSIONS. The finding is that the Russian-made polypropylene mesh patch Esfil 
and the Polish Optomesh had the smallest fibrous capsules formed around them. The German B. Braun and the Italian Ergon had the most intensive post-implantation fibrous tissue growth.

The largest fibrous capsules emerged in rats implanted with Dualmesh (Gore-Tex, USA) and Ti Silk patches.

These findings contradict the manufacturer-claimed properties of these patches, a fact that should be noted when selecting a patch for alloplasty of ventral and groin hernias.

\section{FINANCIAL SUPPORT AND SPONSORSHIP}

Nil.

\section{CONFLICTS OF INTEREST}

The authors declare no conflict of interest

\section{SUPPLEMENTARY DATA (DOI)}

\section{REFERENCES}

1. Chistyakov D.B., Movchan K.N., Yaschenko A.S. The question of differential selection of modern technologies hernioplasty in treatment of patients with postoperative ventral hernias [K voprosu o differentsirovannom vybore sovremennykh tekhnologii gernioplastiki pri lechenii bol'nykh posleoperatsionnymi ventral'nymi gryzhami ]. Modern problems of science and education Sovremennye problemy nauki $i$ obrazovaniia, 2015, no. 5, available at: http://scienceeducation.ru/ru/article/view?id=21604. (accessed 15.07.2019).

2. Magomedov M.M., Imanaliev M.R., Ismailov G.M. et al. Assessment of the results of different methods of prosthetic hernia repain and creterias predicting the developement of early postoperative complicafions. [Otsenka rezul"tatov razlichnykh sposobov proteziruiushchei gernioplastiki i kriterii prognozirovaniia razvitiia rannikh posleoperatsionnykh oslozhnenii] Journal of new medical technologies - Vestnik novykh meditsinskikh tekhnologii, 2016, vol. 23, no 4, pp. 123-127, doi $10.12737 / 23861$.

3. Vasiliev S.V., Moshkova T.A. Modification of the principles of the ventral wall alloplasty [Modifikatsiia printsipov protezirovaniia briushnoi stenki]. The Scientific Notes of the Pavlov University - Uchenye zapiski SPbGMU im. akad. I.P. Pavlova, 2014, vol. 21, no 2, pp. 60-62, doi 10.24884/1607-4181-2014-21-2-60-62.

4. Sukovatykh B.S., Ivanov A.V., Valuskaya N.M. et al. The influence of late implantation fabric reaction on the choice of polypropylene endoprosthesis for preventive subaponeurotic plasty of the abdominal wall. [Vliianie pozdnei implantatsionnoi tkanevoi reaktsii na vybor polipropilenovogo endoproteza dlia preventivnoi podaponevroticheskoi plastiki briushnoi stenki]. Surgery news - Novosti Khirurgii, 2013, vol. 21, no 5, pp. 11-17, doi 10.18484/2305-0047.2013.5.11.

5. Sbrodov M.I., Bogdanov D.Iu., Kumukov M.B. Up-to-date implants in herniology. [Sovremennye implantatsionnye sistemy v gerniologii]. Endoscopic surgery - Endoskopicheskaya khirurgiya, 
2013, vol. 19, no 6, pp. 55-63.

6. Cherkasov M.F., Khindikaynen A.Yu., Pomazkov A.A. Methods of diagnosis, prevention and treatment of complications of hernia repair [Metody diagnostiki, profilaktiki i lecheniia oslozhnenii gernioplastiki]. Astrakhan Medical Journal - Astrakhanskii meditsinskii zhurnal, 2016, vol. 11, no 4, pp. 5064.

7. Chistiakov D.B., Movchan K.N., Iashchenko A.S.. Risks of formation of adhesions during intraabdominal implantation into abdominal wall of mesh prostheses made of ambiguous materials with different bioenergic properties [Riski obrazovaniia spaek pri intraabdominal'noi implantatsii v briushnuiu stenku setchatykh protezov, izgotovlennykh iz neodnoznachnykh materialov, obladaiushchikh raznymi bioenertnymi svoistvami]. Bulletin of the Russian Military Medical Academy Vestnik Rossiiskoi voenno-meditsinskoi akademii, 2016, no 2, pp. 164-169.

8. Anurov M.V., Khachatrian G.V., Titkova S.M. Comparative Study of Seamless Methods of Fixation of Pulmonary Surgical Nets on Hernial Model in Rats [Sravnitel'noe issledovanie besshovnykh metodov fiksatsii legkikh khirurgicheskikh setok na gryzhevoi modeli u krys]. Bulletin of Experimental Biology and Medicine - Biulleten' eksperimental'noi biologii i meditsiny, 2017, vol. 163, no 6, pp. 788-792.

9. Mamedov R.A. Morphological estimation of the local reaction of an organism at application of mesh materials for prosthetics of anterior abdominal wall. [Morfologicheskaia otsenka mestnoi reaktsii organizma pri primenenii setchatykh materialov dlia protezirovaniia perednei briushnoi stenki]. Surgery news - Novosti Khirurgii, 2013, vol. 21, no 1, pp. 23-28, doi 10.18484/23050047.2013.1.23.

10. Mishina E.S., Zatolokina M.A., Netyaga A.A. Reactive changes of connective tissue anterior abdominal wall in the early postoperative period with using experimental samples net endoprosthesis antibacterial coating [Reaktivnye izmeneniia soedinitel'noi tkani perednei briushnoi stenki $\mathrm{v}$ rannem posleoperatsionnom periode pri ispol'zovanii opytnykh obraztsov setchatykh endoprotezov s antibakterial'nym pokrytiem]. Modern problems of science and education Sovremennye problemy nauki $i$ obrazovaniia, 2015, no. 2, available at: http://scienceeducation.ru/ru/article/view?id=18056 (accessed 15.07.2019).

11. Vorovskii O.O. Interaction of composite mesh Implanted With peritoneum abdominoplasty [Vzaimodeistvie implantirovannoi kompozitnoi setki s briushinoi pri abdominoplastike]. I.P. Pavlov Russian Medical Biological Herald - Rossiiskii mediko-biologicheskii vestnik im. akademika I.P. Pavlova, 2013, vol. 21, no 3, pp. 118-123, doi 10.17816/PAVLOVJ20133118-123

12. Parshikov V.V., Mironov A.A., Anikina E.A. To the question about a possibility of use ultra-light titanium- containing mesh in abdominal wall repair in contaminated fields (experimental study) [K voprosu o vozmozhnosti primeneniia ul'tralegkikh titansoderzhashchikh setchatykh endoprotezov dlia plastiki briushnoi stenki v usloviiakh infitsirovaniia (eksperimental'noe issledovanie)]. Pirogov Russian Journal of Surgery - Khirurgiya. Zhurnal imeni N.I. Pirogova, 2016, no 11, pp. 64-70, doi 
10.17116/hirurgia20161164-70 